\title{
T-cell autoreactivity to citrullinated autoantigenic peptides in rheumatoid arthritis patients carrying HLA-DRB1 shared epitope alleles
}

Soi Cheng Law ${ }^{1 \dagger}$, Shayna Street ${ }^{1 \dagger}$, Chien-Hsiung Alan Yu', Christelle Capini', Sakoontalla Ramnoruth ${ }^{1}$, Hendrik J Nel', Eline van Gorp ${ }^{1}$, Claire Hyde ${ }^{1}$, Kim Lau ${ }^{2}$, Helen Pahau', Anthony W Purcell ${ }^{2}$ and Ranjeny Thomas ${ }^{1 *}$

\begin{abstract}
Introduction: Anti-citrullinated peptide antibodies are found in rheumatoid arthritis (RA) patients with HLA-DRß chains encoding the shared epitope (SE) sequence. Citrullination increases self-antigen immunogenicity, through increased binding affinity to SE-containing HLA-DR molecules. To characterise T-cell autoreactivity towards citrullinated self-epitopes, we profiled responses of $\mathrm{SE}^{+}$healthy controls and RA patients to citrullinated and unmodified epitopes of four autoantigens.
\end{abstract}

Methods: We compared T-cell proliferative and cytokine responses to citrullinated and native type II collagen 1,237 to 1,249, vimentin 66 to 78, aggrecan 84 to 103 and fibrinogen 79 to 91 in six SE' healthy controls and in 21 RA patients with varying disease duration. Cytokine-producing cells were stained after incubation with peptide in the presence of Brefeldin-A.

Results: Although proliferative responses were low, IL-6, IL-17 and TNF were secreted by $\mathrm{CD}^{+} \mathrm{T}$ cells of SE $\mathrm{RA}^{+}$ patients and healthy controls, as well as IFN $\gamma$ and IL-10 secreted by RA patients, in response to citrullinated peptides. Of the epitopes tested, citrullinated aggrecan was most immunogenic. Patients with early RA were more likely to produce IL-6 in response to no epitope or to citrullinated aggrecan, while patients with longstanding RA were more likely to produce IL-6 to more than one epitope. Cytokine-producing CD4 ${ }^{+} \mathrm{T}$ cells included the $\mathrm{CD}_{5} \mathrm{RO}^{+}$and $\mathrm{CD} 45 \mathrm{RO}^{-}$and the $\mathrm{CD}^{+} 8^{+}$and $\mathrm{CD}^{-} 8^{-}$subsets in RA patients.

Conclusion: Proinflammatory cytokines were produced by $\mathrm{CD}^{+} \mathrm{T}$ cells in $\mathrm{SE}^{+}$individuals in response to citrullinated self-epitopes, of which citrullinated aggrecan was most immunogenic. Our data suggest that the T-cell response to citrullinated self-epitopes matures and diversifies with development of RA.

\section{Introduction}

Rheumatoid arthritis (RA) is an autoimmune disease characterised by inflammation of joint synovial tissue and deformity and destruction of associated bone, cartilage and soft tissues. Several autoantigens are described in RA, including a variety of proteins that become citrullinated in diseased joints. Citrullination is a physiological process of arginine deimination that occurs during apoptosis and inflammation. This process results in modification of arginine-containing proteins, which can

\footnotetext{
* Correspondence: ranjeny.thomas@uq.edu.au

+ Contributed equally

'The University of Queensland Diamantina Institute, Princess Alexandra Hospital, Brisbane, Qld 4102, Australia

Full list of author information is available at the end of the article
}

give rise to sets of neo-self-antigens in individuals bearing at-risk HLA alleles [1].

Specific HLA-DR gene variants mapping to amino acids 70 to 74 of the third hypervariable region of DR $\beta$ chains are highly associated with RA [2]. This region encodes a conserved amino acid sequence that forms the fourth anchoring pocket (P4) in the HLA-DR antigen-binding groove. This shared susceptibility epitope (SE) is found in multiple RA-associated DR alleles, including DRB1*0401, DRB1*0404 and DRB*0101 in Caucasians [2]. The SE-encoding HLA alleles are particularly associated with anti-citrullinated protein autoantibody (ACPA)-positive RA [3-5]. The SE is highly positively charged, and is situated in a region of the

\section{C) Biomed Central}


DR $\beta$ chain that influences the specificity of the P4 amino acid of the bound ligand. The SE would therefore preferentially bind peptides containing a negatively charged or nonpolar amino acid at this position.

Citrullination replaces charged arginine amino sidechain groups with an uncharged carbonyl group, and has been shown to be permissive of binding of a human vimentin peptide epitope to $\mathrm{SE}^{+}$HLA DR molecules through increased affinity with P4 [6,7]. While the dominant B-cell vimentin, fibrinogen and collagen type II epitopes in RA are citrullinated, evidence is just emerging that $\mathrm{T}$ cells show specificity towards citrullinated over the corresponding native epitopes [7].

Approximately $70 \%$ of RA patient sera contain ACPAs [8]. This reactivity reflects autoantibody production towards a group of citrullinated autoantigens modified post-translationally, including fibrinogen, vimentin, collagen type II and enolase [9]. ACPAs develop up to 15 years prior to the onset of RA, with increasing titres and peptide reactivities as disease onset becomes imminent [10]. Citrullinated proteins have been demonstrated in inflamed tissues in RA, and ACPAs are induced in a number of mouse models of inflammatory arthritis [11-14]. Although citrullination is ubiquitous in response to stress and inflammation, ACPAs are highly specific for RA and are associated with more severe joint damage and radiographic outcome $[3,4,8]$.

Immunisation of HLA-DRB1*0401 transgenic mice with citrullinated fibrinogen, but not native fibrinogen, induced inflammatory arthritis characterised by simultaneous B-cell and T-cell autoreactivity to citrullinated and native HLA-DR-restricted fibrinogen epitopes, which was not present in naïve HLA-DRB1*0401 transgenic mice [15]. Furthermore, recent studies suggest that delivery of the costimulation modulator, abatacept, may restore tolerance towards citrullinated antigens [16]. Notwithstanding these studies in transgenic mice, citrulline-specific autoreactive $\mathrm{T}$ cells have been difficult to demonstrate in RA patients due to the weak proliferative responses made by autoreactive effector memory $\mathrm{T}$ cells in vitro. However, several recent papers have shown convincing cytokine responses made by RA patient $\mathrm{T}$ cells in response to citrullinated vimentin and aggrecan epitopes $[7,17]$. In the case of vimentin, the immunogenicity of the epitope was dependent on the location of the citrulline modification within the peptide sequence [7].

In the current studies, we profiled the responses of SE ${ }^{+}$healthy controls and RA patients towards a set of citrullinated and unmodified (native) self-antigens, and characterised the responding $\mathrm{T}$ cells. Our aim was to identify citrullinated epitopes that may be of particular relevance in $\mathrm{ACPA}^{+} \mathrm{RA}$, and to determine the extent of individual variability among citrullinated autoantigenic
T-cell responses. Further, we wished to identify $T$ cells that may contribute to the development of $\mathrm{ACPA}^{+} \mathrm{RA}$. Of four citrullinated autoantigenic peptides, we identified citrullinated aggrecan 84 to 103 as the most immunogenic, and we identified IL- 6 production by T cells as an important biomarker of response.

\section{Materials and methods \\ Patients}

Twenty-one patients who fulfilled the 1987 American College of Rheumatology criteria for RA [18] and six $\mathrm{ACPA}^{-} \mathrm{SE}^{+}$healthy controls were included. All individuals provided peripheral blood (PB) samples, although in some cases the yield was insufficient for all assays. Patient demographic details are outlined in Table 1. HLA-DR genotyping was carried out at Queensland Health Pathology Services. The study was approved by the Human Research Ethics Committee of the Princess Alexandra Hospital and informed consent was obtained from each patient.

\section{Peptide preparation}

Citrulline or arginine-containing SE-binding epitopes were synthesised from vimentin, collagen type II, fibrinogen and aggrecan (Auspep Tullamarine VIC, Australia). All peptides were filtered, reconstituted to $300 \mu \mathrm{g} /$ $\mathrm{ml}$ in sterile water and stored at $-70^{\circ} \mathrm{C}$. Final dilutions for the working stock were made with medium.

\section{Purification of peripheral blood mononuclear cells and antigen presentation assays}

Peripheral blood mononuclear cells (PBMC) were isolated using Ficoll-Paque density gradients (GE Healthcare, Piscataway, New Jersey, United States), washed with $0.9 \%$ saline and then resuspended in RPMI containing 10\% human serum from healthy or autologous or allogeneic RA donors. Tetanus toxoid was used at a concentration of 4 Lfi/ml (Chiron Vaccines, Mumbai, Maharashtra, India). Two $\times 10^{5}$ PBMC or SFMC were incubated with 0,3 and $30 \mu \mathrm{g} / \mathrm{ml}$ of each peptide in the presence of RPMI containing $10 \%$ human serum in a final volume of $200 \mu \mathrm{l}$ in round-bottomed wells for 5 days. T-cell proliferation was assessed by addition of $1 \mu \mathrm{Ci} /$ well $\left[{ }^{3} \mathrm{H}\right]$ thymidine (ICN Biochemicals Costa Mesa, CA, USA) for the final 18 hours. Cells were harvested onto glass-fibre filter mats and $\left[{ }^{3} \mathrm{H}\right]$ thymidine incorporation was determined by liquid scintillation spectroscopy (Packard Topcount; Packard Instrument Co. Meridien, CT, USA). IL-2, IL-4, IFN $\gamma$, IL10, IL-6, IL-17 and TNF were measured in the day 5 supernatants using BD Cytometric Bead Array kits (BD Bioscience, San Jose, CA, USA).

Initial kinetic experiments demonstrated that peptide stimulation for 5 days optimally induced antigen-specific proliferative and cytokine responses, and that longer 
Table 1 Characteristics of patients in the study

\begin{tabular}{|c|c|c|c|c|c|c|c|}
\hline Patient & Ethnicity & $\begin{array}{l}\text { HLA-DRB1 } \\
\text { genotype }\end{array}$ & ACPA & $\begin{array}{l}\text { Disease duration } \\
\text { (years) }\end{array}$ & Treatment & $\begin{array}{l}\text { C-reactive protein }{ }^{a}(\mathrm{mg} / \\
\text { I) }\end{array}$ & Representation \\
\hline$\overline{\mathrm{RA} 1}$ & Caucasian & 03,0401 & + & 6 & $M, S$ & 8 & Figure 1 \\
\hline RA2 & Caucasian & 03,0401 & + & $<1$ & Nil & 3 & Figures 1 to 5 \\
\hline RA3 & $\begin{array}{l}\text { Caucasian/Pacific } \\
\text { Islander }\end{array}$ & 0403,0405 & - & $<1$ & $\mathrm{M}, \mathrm{S}, \mathrm{H}$ & 3 & Figure 1 \\
\hline RA4 & Caucasian & 0401,0404 & + & $<1$ & L & 11 & Figures 1 to 5 \\
\hline RA5 & Caucasian & 0404,1302 & + & 1 & $\mathrm{M}, \mathrm{S}, \mathrm{H}$ & 2 & Figure 1 \\
\hline RA6 & Caucasian & 040113 & + & $>5$ & $\mathrm{M}, \mathrm{H}$ & 1 & Figures 1 to 5 \\
\hline RA7 & Asian & 0405 & - & 1 & M & 1 & Figures 1 to 5 \\
\hline RA8 & Caucasian & 0401,0404 & + & $>5$ & $\mathrm{~L}, \mathrm{H}, \mathrm{S}$ & 22 & Figures 1 to 5 \\
\hline RA9 & Caucasian & 0103,0101 & + & $<1$ & Nil & 4 & Figures 1 to 5 \\
\hline RA10 & Caucasian & 01,1302 & + & 5 & $\mathrm{H}$ & 10 & Figures 1 to 5 \\
\hline RA11 & Caucasian & 04,0301 & - & 4 & $M, S, H$ & 3 & Figures 1 to 5 \\
\hline RA12 & Caucasian & 0401 & + & 0 & Nil & 45 & Figures 1 to 5 \\
\hline RA13 & Caucasian & 0101,1301 & - & $>5$ & M & 20 & Figures 1 to 6 \\
\hline RA14 & Caucasian & 0408,11 & + & $>5$ & $\mathrm{M}, \mathrm{S}, \mathrm{H}$ & 4.6 & Figures 1 to 6 \\
\hline RA15 & Caucasian & 0401,0408 & + & 0 & Nil & 1 & Figures 1 to 6 \\
\hline RA16 & Caucasian & 0101,0408 & + & 0 & Nil & 6 & Figures 1 to 6 \\
\hline RA17 & Caucasian & 0401, 03 & + & $>5$ & $\mathrm{M}, \mathrm{A}$ & 33 & Figure 6 \\
\hline RA18 & Caucasian & 0401,03 & + & 3 & M & 2 & Figures 1 to 5 \\
\hline RA19 & Caucasian & 0101,0103 & + & 2 & $\mathrm{M}, \mathrm{S}, \mathrm{H}$ & 5.3 & Figures 1 to 5 \\
\hline RA20 & Caucasian & 0401, 1501 & + & 2 & - & 9.9 & Figures 1 to 5 \\
\hline RA21 & Caucasian & 0401, 0101 & + & $>5$ & $M, P$ & 2 & Figures 1 to 5 \\
\hline $\mathrm{HC} 1$ & Caucasian & 01 & - & & & & Figures 1 to 5 \\
\hline $\mathrm{HC2}$ & Caucasian & 03,04 & - & & & & Figures 1 to 5 \\
\hline $\mathrm{HC} 3$ & Caucasian & 0401, 0701 & - & & & & Figures 1 to 5 \\
\hline $\mathrm{HC} 4$ & Caucasian & 0101, 08 & - & & & & Figures 1 to 5 \\
\hline HC5 & Caucasian & 1301,0401 & - & & & & Figures 1 to 6 \\
\hline HC6 & Caucasian & 0401,1301 & - & & & & Figures 1 to 6 \\
\hline
\end{tabular}

A, abatacept; $A C P A$, anti-citrullinated peptide antibody; $\mathrm{H}$, hydroxychloroquine; $\mathrm{L}$, leflunomide; $\mathrm{M}$, methotrexate; $\mathrm{S}$, sulfasalazine; $\mathrm{P}$, prednisone. For rheumatoid arthritis (RA) patients, mean age is 50 (range 22 to 65 ), $90 \%$ female; for healthy control (HC) individuals, mean age is 38 (40 to 45 ), $50 \%$ female. ${ }^{a}$ Measured at the time of blood withdrawal for peptide response.

cultures did not yield greater responses. Where RA serum was used in cytokine production assays, $150 \mu \mathrm{g} /$ ml HeteroBlock (Omega Biologicals Bozeman, MT, USA) were added during BD Cytometric Bead Array measurement [19]. Samples were read on the BD FACSArray ${ }^{\mathrm{TM}}$ bioanalyser system.

Stimulation indices for proliferative responses were calculated as the fold increase in response to peptide over background. Net cytokine secretion was calculated for each response as the concentration with peptide stimulation minus the concentration without peptide stimulation. Positive response thresholds were two standard deviations above the cytokine responses towards the corresponding native peptide, for both RA patients and healthy controls.

Flow cytometry and intracellular cytokine staining PBMC from $\mathrm{SE}^{+} \mathrm{RA}$ patients or healthy controls were incubated without or with peptides at concentrations of 3 and $30 \mu \mathrm{g} / \mathrm{ml}$ for 5 days, with Brefeldin-A (Sigma Aldrich St Louis, MO, USA) added for the final 18 hours. Cells were stained for CD3-FITC, CD4-APC/ Cy7, CD28-FITC, CXCR5-PerCP/Cy5.5 and CD45ROPerCP/Cy5.5 (Biolegend, San Diego, CA, USA), followed by permeabilisation and staining for intracellular IL-6-APC and IFN $\gamma$-APC (Biolegend). Data were collected on the Gallios flow cytometer and analysed using Kaluza software (Beckman Coulter, Indianapolis IN, USA).

\section{Statistical analysis}

One-way nonparametric analysis of variance with posthoc correction (Kruskal-Wallis test) compared multiple means. Unpaired Mann-Whitney tests compared the tetanus toxoid proliferative responses between RA patients and healthy controls and compared specific cytokine responses with citrullinated versus native peptides. Significance is indicated as $P<0.05, P<0.01$ and 
$P<0.001$. All error bars represent the standard error of the mean.

\section{Results \\ T cells proliferate poorly but produce cytokines in response to citrullinated autoantigenic peptides}

We synthesised citrullinated or unmodified peptide antigens from the fibrinogen, vimentin, collagen type II and aggrecan protein sequences that had been identified either based on predicted binding capacity to RA-associated DR molecules in a molecular model positioning citrulline at $\mathrm{P} 4$, or through previous studies in HLADR4-IE-transgenic mice (Table 2) $[6,15,17]$. In total, we studied $21 \mathrm{SE}^{+} \mathrm{RA}$ patients and six $\mathrm{SE}^{+}$healthy controls. All except four RA patients were also $\mathrm{ACPA}^{+}$(Table 1). Forty-three per cent of the RA patients were nonsmokers, $38 \%$ past smokers and 19\% current smokers. One healthy control was a current smoker, and two controls had a family history of RA. We analysed the proliferative response of PBMC from $\mathrm{SE}^{+} \mathrm{RA}$ patients and $\mathrm{SE}^{+}$ healthy controls to varying concentrations of citrullinated or unmodified peptide antigen. Proliferative responses to peptide antigens and tetanus toxoid were expressed as stimulation indices. The mean proliferative stimulation indices to citrullinated and unmodified peptides were generally between 1 and 2 in RA patients and healthy controls, and were significantly lower in each case than the responses to tetanus toxoid (Figure 1). The proliferative stimulation indices in response to citrullinated aggrecan peptide were significantly higher than those to native aggrecan peptide in RA patients (Figure 1). Proliferative responses to tetanus toxoid were significantly lower when comparing RA PBMC with healthy control PBMC.

In initial experiments we determined that background cytokine secretion and proliferative responses were generally lower if peptide responses were assayed in the presence of human rather than foetal calf serum. Moreover, there was no difference in cytokine production when comparing assays carried out in the presence of $10 \%$ healthy or autologous or allogeneic RA donor serum, provided HeteroBlock was added when rheumatoid factor titres were $>100 \mathrm{U} / \mathrm{ml}$ (data not shown) to prevent rheumatoid factor from binding capture and detection antibodies in ELISA reactions [19]. In the absence of peptide stimulation, RA patient PBMC secreted significantly higher concentrations of IFN $\gamma$ and IL- 6 than of TNF and IL-10, secreted by either RA patients or healthy controls in the absence of peptides (Figure 2A). Net cytokine secretion was estimated as cytokine secreted upon stimulation with citrullinated peptides minus cytokine secreted in the absence of peptides. IL- 6 secretion was highest of the cytokines measured, with net production of up to $60 \mathrm{ng} / \mathrm{ml}$ in response to $30 \mu \mathrm{g} / \mathrm{ml}$ citrullinated aggrecan.

Consistent with the lack of binding of native epitopes to shared epitope HLA-DR alleles [7] (and unpublished data), RA patients produced significantly greater amounts of IL-6, TNF and IL-10 in response to citrullinated than native aggrecan peptides (Figures $2 \mathrm{~B}$ and 3 ). IL-17 and to some extent IFN $\gamma$ were also secreted in response to several citrullinated peptides, but there was considerable variability among individuals and none of the differences was statistically significant (Figure 3). IL2 and IL-4 responses were generally low (data not shown). When comparing RA patients and healthy controls, RA patients secreted significantly more IL-10 and TNF in response to citrullinated aggrecan than healthy controls $(P<0.05)$, and there was a similar trend for IL17 secretion in response to citrullinated aggrecan $(P=$ $0.065)$ and citrullinated fibrinogen $(P=0.08)$.

Given the lack of stable HLA-DR binding of native self-peptides, we determined positive responses to citrullinated peptides to be greater than a threshold of the mean and two standard deviations above responses to the corresponding native peptides (citrullinated vimentin responses could not be assessed as responses to native vimentin were not measured). When compared with SE ' healthy controls, $\mathrm{SE}^{+} \mathrm{RA}$ patients' citrullinated peptide responses produced a more diverse array of cytokines. Notably, when the percentage of RA patients and healthy controls with positive responses to each citrullinated peptide was plotted, the regulatory cytokines IL10 and IFN $\gamma$ were only produced by RA patients for the tested epitopes (Figure 4).

\section{IL-6 response among RA patients varies with disease duration}

To better understand the citrullinated peptide response pattern of individual RA patients and $\mathrm{SE}^{+}$healthy controls, we plotted IL-6 dose-response curves for each peptide for each individual in the study. PBMC from

Table 2 Sequences of peptides used in the study

\begin{tabular}{lll}
\hline Native peptide sequence & Citrullinated peptide sequence & Human native protein \\
\hline QDFTNRINKLKNS & QDFTNCitINKLKNS & Fibrinogen- $\alpha 79$ to 91 \\
WLLVATEGRVRVNSAYQDK & WLLVATEGCitVRVNSAYQDK & Aggrecan 84 to 103 \\
SAVRARSSVPGVR & SAVRACitSSVPGVR & Vimentin 66 to 78 \\
QYMRADQAAGGLR & QYMCitADQAAGGLR & Collagen II 1,237 to 1,249 \\
\hline
\end{tabular}



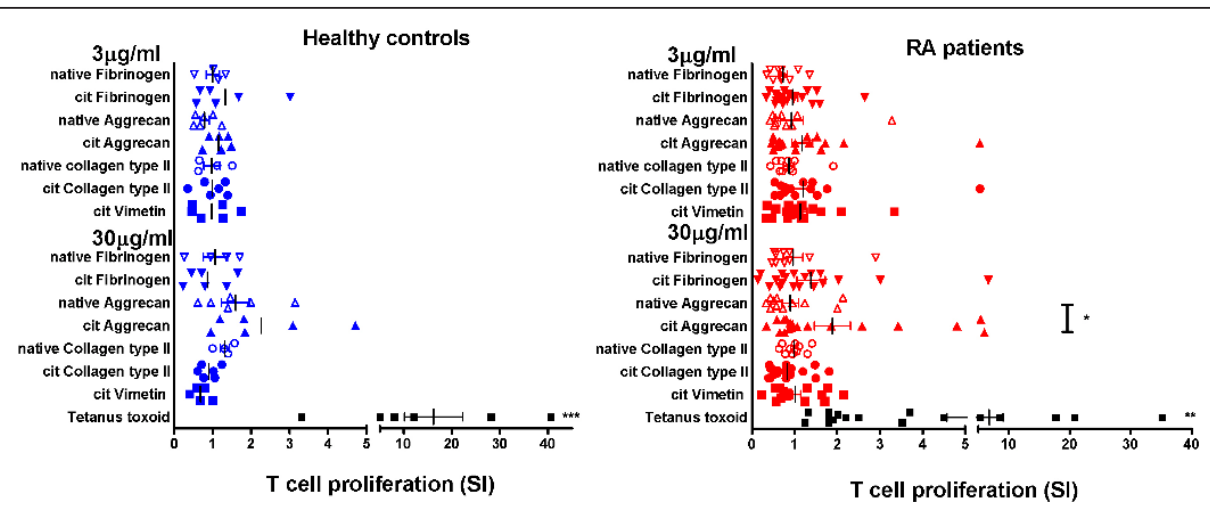

Figure 1 T-cell proliferative response of healthy controls and rheumatoid arthritis patients stimulated with peptides. Peripheral blood mononuclear cells (PBMC) from 20 rheumatoid arthritis (RA) patients and six healthy controls were incubated with 0,3 or $30 \mu \mathrm{g} / \mathrm{ml}$ citrullinated (cit) and native peptides or $4 \mathrm{Lfi} / \mathrm{ml}$ tetanus toxoid, as shown, for 5 days. T-cell proliferation was assessed by uptake of $\left[^{3} \mathrm{H}\right]$ thymidine. Each dot represents one individual. ${ }^{* *} P<0.001$ for RA patients and ${ }^{* *} P<0.01$ for healthy controls comparing multiple means (Kruskal-Wallis test). ${ }^{*} P<$ 0.01 comparing healthy controls and RA patient PBMC for the response to tetanus toxoid (Mann-Whitney test). ${ }^{*} P<0.05$ comparing RA patients' responses to citrullinated and native aggrecan peptides (Mann-Whitney test). SI, stimulation indices.
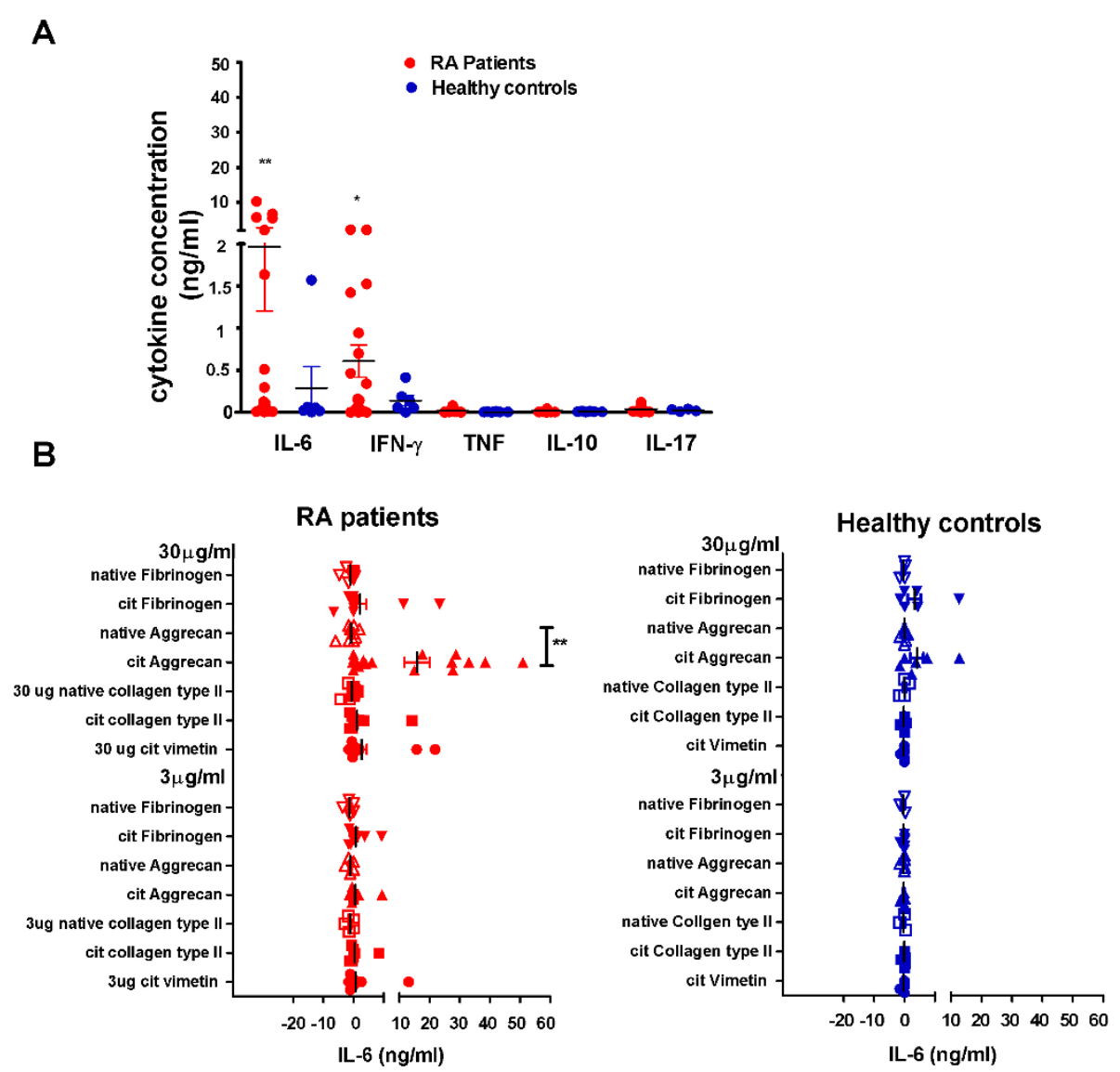

Figure 2 Unstimulated cytokine secretion and net IL-6 secretion by peripheral blood mononuclear cells stimulated with peptides. (A) Peripheral blood mononuclear cells (PBMC) from 17 rheumatoid arthritis (RA) patients and six healthy controls were incubated in medium for 5 days and cytokines were assessed in supernatants by the BD Cytometric Bead Array. ${ }^{*} P<0.01,{ }^{*} P<0.05$ (Kruskal-Wallis test with post-hoc correction). (B) PBMC from 17 RA patients and six healthy controls were incubated with 0,3 or $30 \mu \mathrm{g} / \mathrm{ml}$ citrullinated (cit) and native peptides as shown, and IL-6 was assessed in supernatants by the BD Cytometric Bead Array. Net cytokine secretion was calculated as the IL-6 concentration with peptide stimulation minus the IL-6 concentration without peptide stimulation. Each dot represents one individual. ${ }^{*} P<0.05$, ${ }^{* *} P<0.01$ comparing IL-6 responses with citrullinated and native peptides (Mann-Whitney test). 


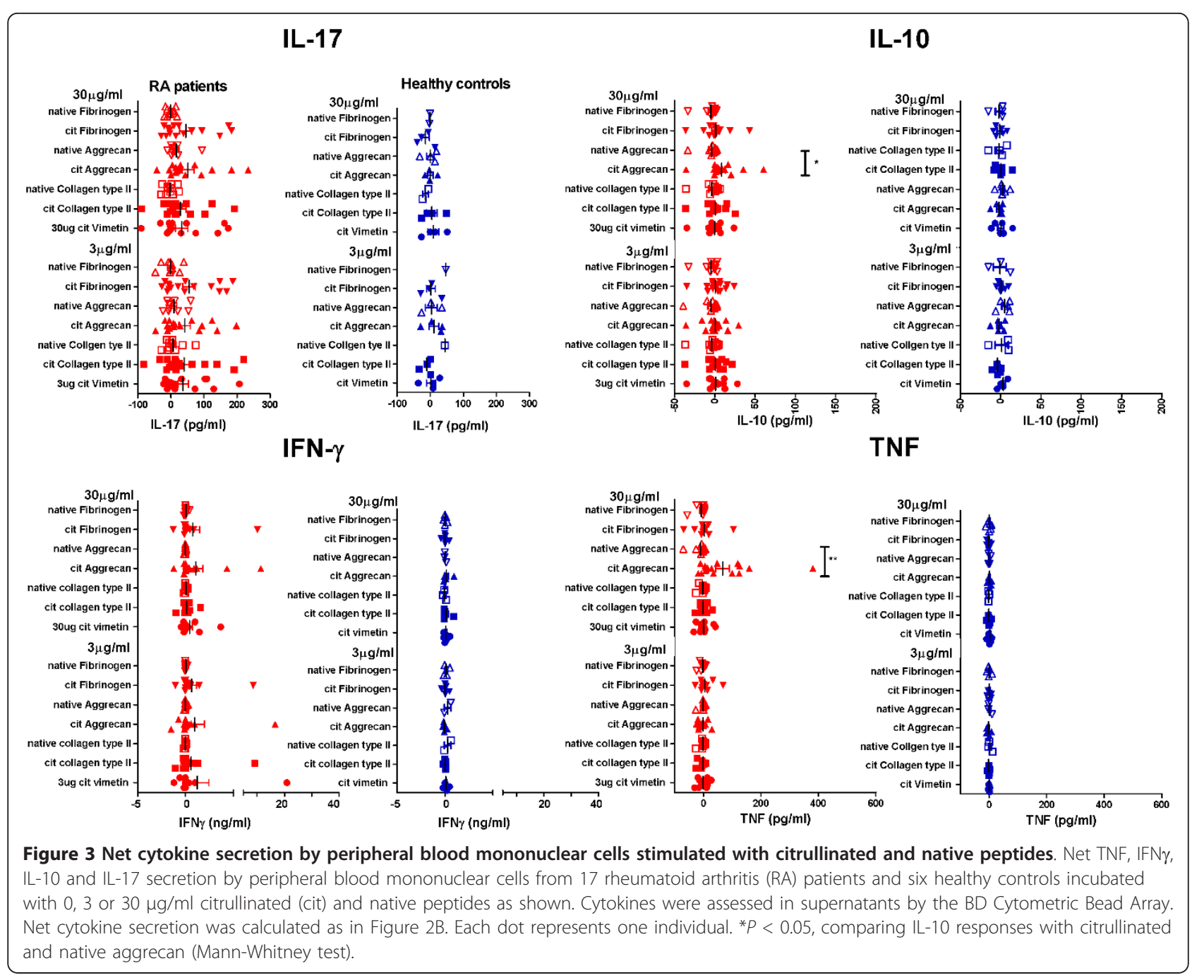

four out of six healthy controls dose-dependently secreted IL- 6 to citrullinated aggrecan and PBMC from three out of six controls secreted IL-6 in response to citrullinated fibrinogen. Taking the same threshold for a positive response as described above, we found that six out of 17 RA patients' PBMC responses secreted IL-6 in

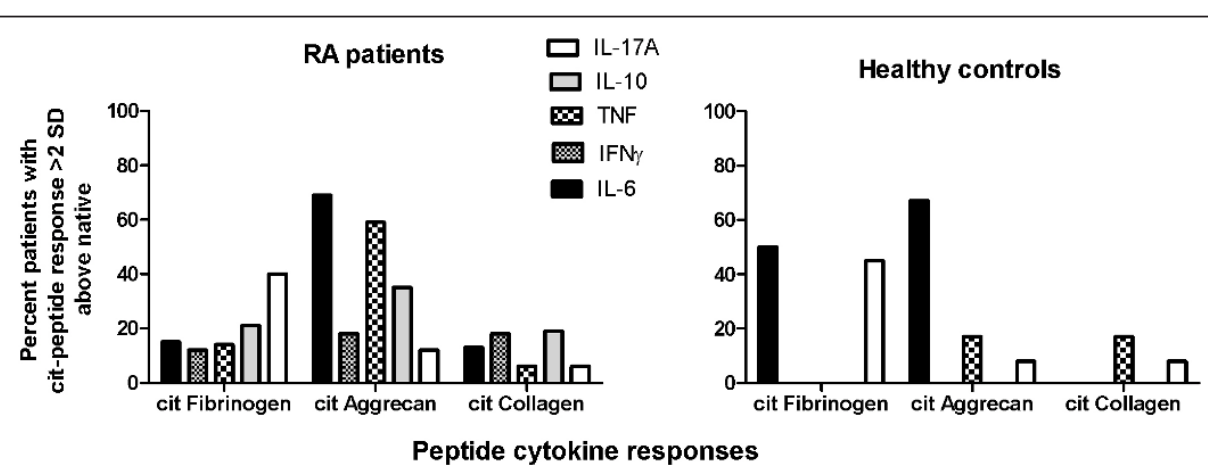

Figure 4 Representation of cytokines produced by rheumatoid arthritis patients and healthy controls. The percentage of rheumatoid arthritis (RA) patients or of healthy controls with positive responses (> 2 standard deviations (SD) above the mean response towards the corresponding native peptide) was calculated for each cytokine, and is plotted for responses to citrullinated (cit) fibrinogen, aggrecan and collagen type II. 
response to no epitopes, eight patients' responses to citrullinated aggrecan only, none to citrullinated fibrinogen, none to citrullinated collagen type II only and three patients' responses to $>1$ citrullinated epitope. IL-6 responses were thus highest and observed most frequently towards citrullinated aggrecan in both RA patients and healthy controls, suggesting this was the most immunogenic epitope tested. An IL-6 response to $>1$ citrullinated epitope occurred more frequently among patients diagnosed with RA at least 5 years previously (Figure 5B).

\section{Effector memory $\mathrm{CD}^{+} \mathrm{T}$ cells secrete cytokines in response to citrullinated peptides}

IL-6 is an important cytokine in RA, which could be produced upon stimulation of PBMC by either $\mathrm{T}$ cells or antigen-presenting cells. To determine the origin of the cytokines secreted into supernatants of PBMC stimulated by citrullinated peptides, we incubated RA
PBMC with citrullinated or native peptides for 5 days, and with addition of Brefeldin-A for the last 18 hours, prior to intracellular cytokine staining along with analysis of cell surface markers. $\mathrm{CD}^{+} \mathrm{CD}^{+}{ }^{+} \mathrm{T}$ cells produced more intracellular IFN $\gamma$ and IL- 6 when incubated with citrullinated aggrecan or fibrinogen relative to incubation in medium alone (Figure 6A, B).

Fluorescence minus one staining demonstrates the gating strategy to determine the threshold for positive staining, as described elsewhere [20] (Figure 6C). No intracellular cytokine staining was observed in these assays by $\mathrm{CD} 4{ }^{-} \mathrm{CD} 28^{-}$cells, most of which represent antigen-presenting cells (Figure 6D). Differentiated or ageing $\mathrm{CD}^{2} 5 \mathrm{RO}^{-}$memory cells have been shown to reexpress CD45RA and to be characterised by the loss of CD27 and CD28 [21]. In healthy controls, CD28- cells comprised only a small proportion of the $\mathrm{CD} 4^{+} \mathrm{T}$ cells, and cytokine-secreting cells were exclusively $\mathrm{CD} 4^{+} \mathrm{CD} 28$ ${ }^{+}$. $\mathrm{CD}^{-} 8^{-}$cells were more abundant among $\mathrm{CD} 4^{+} \mathrm{PB} \mathrm{T}$

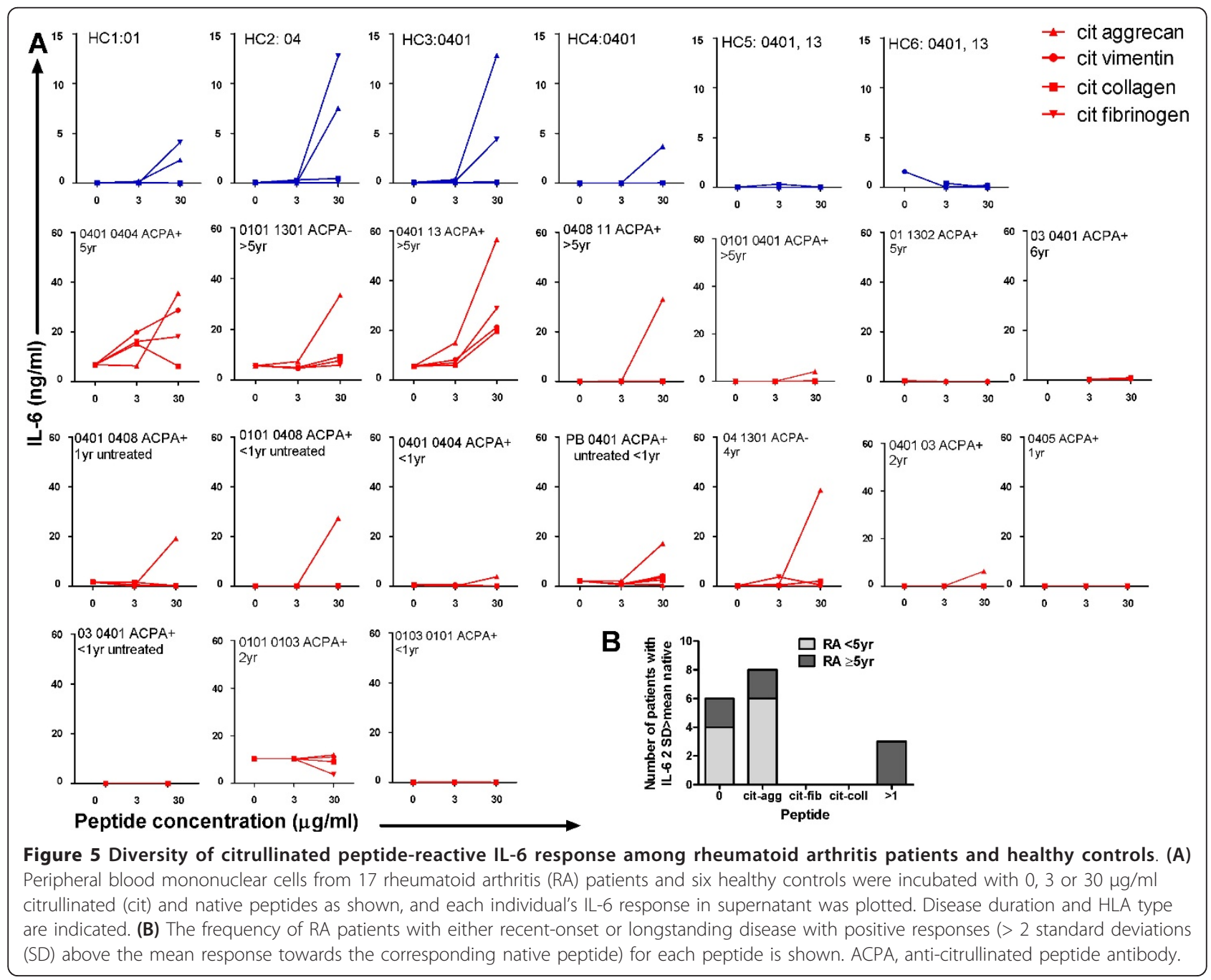




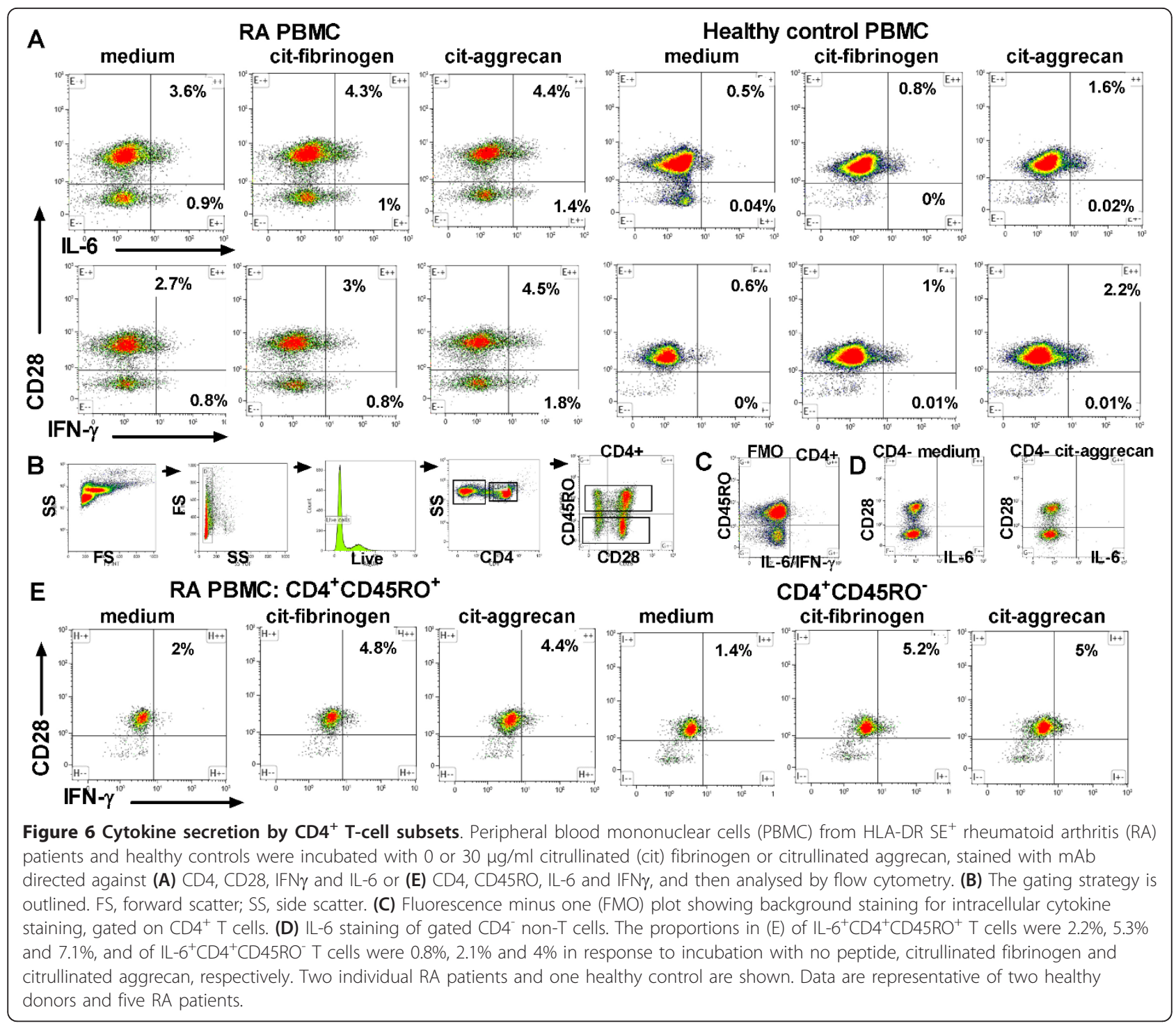

cells in some, but not all, RA patients. Where CD4 ${ }^{+} \mathrm{CD} 28^{-} \mathrm{T}$ cells were present, IL-6 and IFN $\gamma$ were secreted by both $\mathrm{CD} 28^{-}$and $\mathrm{CD} 28^{+} \mathrm{CD} 4^{+} \mathrm{T}$ cells in response to citrullinated peptides. We noted high background cytokine secretion in these cultures, as we had observed earlier in analysis of supernatants (Figures 2A and $6 \mathrm{~A})$. IFN $\gamma^{+} \mathrm{CD} 4^{+}$and IL- $6^{+} \mathrm{CD} 4^{+} \mathrm{T}$ cells included both $\mathrm{CD}_{45 \mathrm{RO}^{+}}$and $\mathrm{CD}^{2} 5 \mathrm{RO}^{-}$cells (Figure 6E). CXCR5 ${ }^{+}$follicular helper $\mathrm{T}$ cells did not express IL-6 or IFN $\gamma$ in response to citrullinated peptides (data not shown).

\section{Discussion}

We have shown here that proinflammatory and regulatory cytokines, including IL-6, IFN $\gamma$ IL-10 and TNF, were produced by $\mathrm{CD}^{+}{ }^{+} \mathrm{T}$ cells in $\mathrm{SE}^{+} \mathrm{RA}$ patients in response to citrullinated self-epitopes, of which citrullinated aggrecan was most immunogenic. These cytokine responses were observed in spite of weak peptide-specific $\mathrm{T}$-cell proliferative responses. $\mathrm{SE}^{+}$healthy controls also produced cytokines in response to citrullinated aggrecan and citrullinated fibrinogen. Such T-cell responses are not necessarily causally related to RA rather, they demonstrate the autoreactivity present in SE ${ }^{+}$individuals towards citrullinated self-peptides, even in the absence of ACPAs. Cytokine responses to citrullinated self-epitopes, however, were more diverse in RA patients than in healthy control individuals. Indeed, only RA patients secreted the regulatory cytokines IL-10 and IFN $\gamma$ in response to these epitopes [22]. IFN $\gamma$ production by $\mathrm{PB}$ and synovial $\mathrm{T}$ cells is well described [23], and IFN-regulated genes have been shown to be predictive of RA development in $\mathrm{ACPA}^{+}$patients with arthralgia [24]. Using intracellular staining we demonstrated IL- 6 and IFN $\gamma$ production by memory $\mathrm{CD} 4^{+} \mathrm{T}$ cells but 
not by CD4- antigen-presenting cells in these cultures, at least when examined after 5 days of peptide stimulation. These data demonstrate that $\mathrm{CD} 4^{+} \mathrm{T}$ cells were capable of cytokine production but do not exclude the possibility that CD4- antigen-presenting cells such as monocytes, B cells and dendritic cells could also produce these cytokines during the culture, which could be secreted into the supernatant. IL- 6 responses increased dose-dependently in response to citrullinated peptides. Intracellular cytokine staining confirmed a broad cytokine response profile, consistent with the phenotype of memory CD4. ${ }^{+} \mathrm{T}$ cells.

Various mechanisms could contribute to the low proliferative response exhibited by autoreactive $\mathrm{T}$ cells to self-peptides and tetanus toxoid antigen in RA. For instance, a number of studies implicate deficient signalling of RA $\mathrm{T}$ cells through the $\mathrm{T}$-cell receptor-CD3 complex [25-31]. IL-2 might be rapidly consumed through binding to the high avidity CD25 receptor expressed by regulatory $\mathrm{T}$ cells and by effector memory $\mathrm{T}$ cells upon activation. This could limit availability of IL-2 for T-cell proliferation in tissue culture [32,33]. Furthermore, autoreactive $\mathrm{T}$ cells are subject to the influence of regulatory cells and cytokines, as demonstrated here [34,35]. On the other hand, effector memory cells produce high levels of proinflammatory and regulatory cytokines, and cytokine production more effectively interrogates highly differentiated autoreactive effector memory $\mathrm{T}$ cells in both humans and mice [36-38].

The proinflammatory cytokine IL-6 stimulates B-cell antibody production and plays a critical role in RA pathogenesis [39]. In RA patients, intracellular IL-6 and IFN $\gamma$ were produced by $\mathrm{CD}_{2} 8^{+}$and $\mathrm{CD}_{28}{ }^{-}$and $\mathrm{CD} 45 \mathrm{RO}$ ${ }^{+}$and $\mathrm{CD}_{45 \mathrm{RO}^{-}} \mathrm{PB} \mathrm{CD} 4^{+} \mathrm{T}$ cells. Consistent with the poor proliferative but good cytokine response of RA T cells in response to citrullinated peptides in the current studies, CD $4{ }^{+} \mathrm{CD} 45 \mathrm{RB}^{\mathrm{dim}} \mathrm{CD} 27^{-}$memory $\mathrm{T}$ cells from healthy donors were previously shown to proliferate poorly but to produce large amounts of IL-4 and IL-10 in response to mitogen, and to provide effective B-cell help for immunoglobulin production [40]. In contrast, typical CXCR5 ${ }^{+}$follicular helper $\mathrm{T}$ cells, which have been shown to promote antibody production in lymphoid tissue in vivo [41], did not express cytokines in response to citrullinated peptides. Of interest, where CD28- $\mathrm{T}$ cells were present in $\mathrm{PB}$ of RA patients, they also produced cytokine in response to citrullinated peptides. CD28- $\mathrm{T}$ cells represent an important effector memory amplification response in the synovial environment, and have been shown to be more resistant to suppression by regulatory $\mathrm{T}$ cells $[21,42]$. Together our data support the hypothesis that effector memory $\mathrm{T}$ cells, reactive with a variety of citrullinated self-peptides and with the potential for B-cell help, circulate in $\mathrm{PB}$ of $\mathrm{SE}^{+}$ individuals.

Previous studies in RA patients analysed the PB CD4

+ $\mathrm{T}$-cell response to a single citrullinated peptide specificity. Proliferative and IL-17 CD $4^{+} \mathrm{T}$-cell responses to citrullinated aggrecan 84 to 103 were demonstrated in RA patients but not in healthy controls, demonstrating the immunogenicity of this citrullinated aggrecan epitope [17]. The unmodified aggrecan epitope is immunodominant in BALB/c mice immunised with aggrecan/proteoglycan [43]. This citrullinated aggrecan peptide was also the most immunogenic epitope in the current studies - with the highest frequency of responders, and with the highest magnitude of IL-6 responses. In longstanding RA patients, we also found robust cytokine production in response to citrullinated fibrinogen- $\alpha 79$ to 91 , which was shown to be the immunodominant epitope in HLA-DR4-IE transgenic mice immunised with citrullinated human fibrinogen [15].

Stimulation with the citrullinated vimentin 66 to 78 epitope produced much weaker cytokine responses in the current studies - as was observed by Snir and colleagues, who found that HLA-DRB1*0401 ${ }^{+}$RA patient T cells produced a number of cytokines when incubated with citrullinated vimentin 59 to 78 but not citrullinated vimentin 66 to 78 [7]. In that study, IFN $\gamma$ and TNF were expressed intracellularly by a small proportion of CD $154^{+} \mathrm{CD} 4{ }^{+}$RA patient $\mathrm{T}$ cells in response to citrullinated but not native vimentin 59 to 78 . The proportion of $\mathrm{T}$ cells staining for intracellular cytokine was much lower than in the current studies, in which we carried out staining 5 days after antigen stimulation and without a second restimulation. Anergy may possibly have been induced by restimulation with peptide after an initial 5day culture with peptide - or, given their effector memory phenotype [44], few $\mathrm{T}$ cells were capable of reexpressing CD154 after prolonged in vitro culture. Similar to the current study, Snir and colleagues did not observe strong proliferative or IL-17A responses, unlike von Delwig and colleagues [17].

Differences in cytokine secretion may relate to the inclusion of healthy human serum or of HeteroBlock plus autologous serum in the current studies [19]. Finally, due to the hydrophobic amino acids at 84 to 88 , the citrullinated aggrecan peptide was relatively insoluble in aqueous medium, which may also have affected the antigen purity, concentration and cellular uptake in different laboratories. The greater immunogenicity of citrullinated aggrecan possibly also relates to its length relative to the other peptides. Structural analysis of the HLA-DR binding and T-cell contact residues of these peptides will aid understanding of the $\mathrm{T}$-cell responses observed. 
We observed T-cell cytokine responses to citrullinated self-epitopes in $\mathrm{SE}^{+} \mathrm{RA}$ patients, whether $\mathrm{ACPA}^{+}$or not, as well as in $\mathrm{ACPA}^{-}$healthy controls. HLADRB1*0401 ${ }^{+}$healthy control $\mathrm{T}$ cells were also observed to produce cytokine in response to citrullinated vimentin 59 to 78 [7]. After immunisation of DR4-IE transgenic mice with citrullinated human fibrinogen, responses to unmodified native epitopes were stimulated in parallel with responses to citrullinated epitopes. From the previous and current analyses of HLA-DR binding and responses to unmodified epitopes, responses to citrullinated epitopes appear to be most specific to $\mathrm{SE}^{+}$ RA PB. In contrast, the magnitude and diversity of the responses to citrullinated epitopes in healthy controls was unexpected. $\mathrm{CD}^{+} \mathrm{T}$ cells in both $\mathrm{SE}^{+}$RA patients and HLA-DR $4^{+}$healthy controls have reduced T-cellreceptor excision circles, overall telomere shortening, and reduced replicative capacity, which together imply an HLA-DR SE-associated reduction in T-cell input to the peripheral repertoire, an increased proliferative drive for naïve $\mathrm{T}$ cells towards peripheral self-antigens and a limited diversity of the TCR repertoire [45-47].

Together, studies in humans suggest that PB $\mathrm{T}$ cells in HLA-DR $\mathrm{SE}^{+}$individuals may be predisposed to autoreactivity towards self-antigens, including those modified by citrullination, potentially exposed during stress or proinflammatory settings, including joint trauma or smoking $[3,48]$. Furthermore, unlike T-cell autoreactivity, the development of B-cell autoreactivity towards citrullinated epitopes appears to be a significant checkpoint in the progression to RA. It has been proposed that infection (for example, with Porphyromonas gingivalis in patients with periodontitis) may be a critical trigger for progress through this checkpoint, potentially due to cross-reactivity with bacterial antigens, adjuvant effects of pathogen-associated molecular patterns, targeting of alternative antigen-presenting cells, or a combination of these [9]. Carbamylation of lysine residues to homocitrulline may be another factor enhancing the immunogenicity of RA autoantigens, including citrullinated antigens [49].

Our data suggest that RA patients with longstanding disease may be more likely to respond to more than one citrullinated epitope, whereas patients with recentonset RA (including those previously untreated) appeared generally to respond either to no antigen or only to citrullinated aggrecan. These data suggest the possibility that epitope-spreading occurs as disease progresses. To confirm this hypothesis, a larger sample of RA patients would need to be studied, preferably longitudinally, along with peptide-MHC tetramer reactivity. Furthermore, it would be preferable to study a panel of the most immunogenic citrullinated epitopes, including the citrullinated aggrecan and fibrinogen $\alpha$ epitopes used here, and citrullinated vimentin 59 to 78 [7]. The assay developed here, in which T-cell cytokine production is interrogated in the presence of varying concentrations of a panel of citrullinated epitopes, is likely to be a useful biomarker to identify the most immunogenic peptide epitopes, and to correlate specific $\mathrm{T}$-cell responses with corresponding ACPA fine specificities [50]. These assays would be optimally carried out in conjunction with analysis of tetramer-specific $\mathrm{T}$ cells. Future applications include comparison of serial samples of PBMC from pre-RA through to diagnosis [51], and effects of treatment. The analysis of PBMC from clinical trials of antigen-specific or nonspecific immunotherapy, such as abatacept, would also be of interest [16]. Finally, analysis of specific peptide reactivity may be beneficial for stratifying patients and for identifying appropriate epitopes for personalised antigen-specific immunotherapy.

\section{Conclusion}

Proinflammatory and regulatory cytokines were produced by $\mathrm{CD} 4^{+} \mathrm{T}$ cells in SE-positive individuals in response to citrullinated self-epitopes, of which citrullinated aggrecan was most immunogenic. Our data suggest that the $\mathrm{T}$-cell response matures and diversifies with development of RA.

\section{Abbreviations}

ACPA: anti-citrullinated peptide antibody; IFN: interferon; IL: interleukin; mAb: monoclonal antibody; P4: fourth anchoring pocket; PB: peripheral blood; PBMC: peripheral blood mononuclear cells; RA: rheumatoid arthritis; SE: shared epitope; TNF: tumour necrosis factor.

\section{Acknowledgements}

This work was supported by NHMRC grants 508927 (all authors), 351439 and 569938 (SCL, SS, C-HAY, CC, SR, EvG, CH, HP and RT). RT was supported by Arthritis Queensland and an ARC Future Fellowship, SS by an NHMRC Peter Doherty Fellowship, AWP by an NHMRC Fellowship, and CC by a

Queensland Government Smart State Fellowship and Arthritis Queensland. The funding bodies played no role in the study design, in the collection, analysis, and interpretation of data, in the writing of the manuscript, or in the decision to submit the manuscript for publication.

\section{Author details}

${ }^{1}$ The University of Queensland Diamantina Institute, Princess Alexandra Hospital, Brisbane, Qld 4102, Australia. ${ }^{2}$ Department of Biochemistry and Molecular Biology, The Bio21 Molecular Science and Biotechnology Institute, University of Melbourne, Parkville, Vic 3010, Australia.

\section{Authors' contributions}

SCL, SS, C-HAY, CC, SR, HJN, EVG, CH and KL designed the peptides and carried out immunoassays. HP coordinated the clinical data collection. SCL, SS, CC, AWP and RT conceived the study, participated in its design and coordination, and helped to draft the manuscript. All authors read and approved the final manuscript.

\section{Competing interests}

The authors declare that they have no competing interests.

Received: 30 November 2011 Revised: 20 January 2012 Accepted: 17 May 2012 Published: 17 May 2012 


\section{References}

1. Vossenaar ER, Van Venrooij WJ: Citrullinated proteins: sparks that may ignite the fire in rheumatoid arthritis. Arthritis Res Ther 2004, 6:107-111.

2. Gregersen PK, Silver J, Winchester RJ: The shared epitope hypothesis: an approach to understanding the molecular genetics of suseptibility to rheumatoid arthritis. Arthritis Rheum 1987, 30:1205-1213.

3. Klareskog L, Stolt P, Lundberg K, Kallberg H, Bengtsson C, Grunewald J, Ronnelid J, Harris HE, Ulfgren AK, Rantapaa-Dahlqvist S, Eklund A, Padyukov $L$, Alfredsson $L$ : A new model for an etiology of rheumatoid arthritis: smoking may trigger HLA-DR (shared epitope)-restricted immune reactions to autoantigens modified by citrullination. Arthritis Rheum 2006, 54:38-46

4. van Gaalen FA, van Aken J, Huizinga TW, Schreuder GM, Breedveld FC, Zanelli E, van Venrooij WJ, Verweij CL, Toes RE, de Vries RR: Association between HLA class II genes and autoantibodies to cyclic citrullinated peptides (CCPs) influences the severity of rheumatoid arthritis. Arthritis Rheum 2004, 50:2113-2121.

5. Hida S, Miura NN, Adachi Y, Ohno N: Influence of arginine deimination on antigenicity of fibrinogen. J Autoimmun 2004, 23:141-150.

6. Hill JA, Southwood S, Sette A, Jevnikar AM, Bell DA, Cairns E: Cutting edge: the conversion of arginine to citrulline allows for a high-affinity peptide interaction with the rheumatoid arthritis-associated HLA-DRB1*0401 MHC class II molecule. J Immunol 2003, 171:538-541.

7. Snir O, Rieck M, Gebe JA, Yue BB, Rawlings CA, Nepom G, Malmström V, Buckner JH: Identification and functional characterization of T cells reactive to citrullinated-vimentin in $\mathrm{HLA}-\mathrm{DRB} 1{ }^{*} 0401$ humanized mice and RA patients. Arthritis Rheum 2011, 63:2873-83.

8. Meyer O, Nicaise-Roland P, Santos MD, Labarre C, Dougados M, Goupille P, Cantagrel A, Sibilia J, Combe B: Serial determination of cyclic citrullinated peptide autoantibodies predicted five-year radiological outcomes in a prospective cohort of patients with early rheumatoid arthritis. Arthritis Res Ther 2006, 8:R40.

9. Wegner N, Lundberg K, Kinloch A, Fisher B, Malmstrom V, Feldmann M, Venables PJ: Autoimmunity to specific citrullinated proteins gives the first clues to the etiology of rheumatoid arthritis. Immunol Rev 2010, 233:34-54.

10. van de Stadt LA, de Koning MHMT, van de Stadt RJ, Wolbink G, Dijkmans BAC, Hamann D, van Schaardenburg D: Development of the anti citrullinated peptide antibody repertoire prior to the onset of rheumatoid arthritis. Arthritis Rheum 2011, 63:3226-33.

11. Masson-Bessiere C, Sebbag M, Girbal-Neuhauser E, Nogueira L, Vincent C, Senshu T, Serre G: The major synovial targets of the rheumatoid arthritisspecific antifilaggrin autoantibodies are deiminated forms of the alphaand beta-chains of fibrin. J Immunol 2001, 166:4177-4184.

12. Vossenaar ER, Nijenhuis S, Helsen MM, van der Heijden A, Senshu T, van den Berg WB, van Venrooij WJ, Joosten LA: Citrullination of synovial proteins in murine models of rheumatoid arthritis. Arthritis Rheum 2003, 48:2489-2500

13. Kuhn KA, Kulik L, Tomooka B, Braschler KJ, Arend WP, Robinson WH, Holers VM: Antibodies against citrullinated proteins enhance tissue injury in experimental autoimmune arthritis. J Clin Invest 2006, 116:961-973.

14. Glant TT, Radacs M, Nagyeri G, Olasz K, Laszlo A, Boldizsar F, Hegyi A, Finnegan A, Mikecz K: Proteoglycan-induced arthritis and recombinant human proteoglycan aggrecan G1 domain-induced arthritis in BALB/C mice resembling two subtypes of rheumatoid arthritis. Arthritis Rheum 2011, 63:1312-1321.

15. Hill JA, Bell DA, Brintnell W, Yue D, Wehrli B, Jevnikar AM, Lee DM, Hueber W, Robinson WH, Cairns E: Arthritis induced by posttranslationally modified (citrullinated) fibrinogen in DR4-IE transgenic mice. J Exp Med 2008, 205:967-979.

16. Yue D, Brintnell W, Mannik LA, Christie DA, Haeryfar SMM, Madrenas J, Chakrabarti S, Bell DA, Cairns E: CTLA-4lg blocks the development and progression of citrullinated fibrinogen-induced arthritis in DR4transgenic mice. Arthritis Rheum 2010, 62:2941-2952.

17. von Delwig A, Locke J, Robinson JH, Ng WF: Response of Th17 cells to a citrullinated arthritogenic aggrecan peptide in patients with rheumatoid arthritis. Arthritis Rheum 2010, 62:143-149.

18. Aletaha D, Neogi T, Silman AJ, Funovits J, Felson DT, Bingham CO, Birnbaum NS, Burmester GR, Bykerk VP, Cohen MD, Combe B, Costenbader KH, Dougados M, Emery P, Ferraccioli G, Hazes JM, Hobbs K, Huizinga TW, Kavanaugh A, Kay J, Kvien TK, Laing T, Mease P, Menard HA,
Moreland LW, Naden RL, Pincus T, Smolen JS, Stanislawska-Biernat E, Symmons D, et al: 2010 rheumatoid arthritis classification criteria: an American College of Rheumatology/European League Against Rheumatism collaborative initiative. Arthritis Rheum 2010, 62:2569-2581.

19. Todd DJ, Knowlton N, Amato M, Frank MB, Schur PH, Izmailova ES, Roubenoff R, Shadick NA, Weinblatt ME, Centola M, Lee DM: Erroneous augmentation of multiplex assay measurements in patients with rheumatoid arthritis due to heterophilic binding by serum rheumatoid factor. Arthritis Rheum 2011, 63:894-903.

20. Herzenberg LA, Tung J, Moore WA, Herzenberg LA, Parks DR: Interpreting flow cytometry data: a guide for the perplexed. Nat Immunol 2006, 7:681-685

21. Weng N-P, Akbar AN, Goronzy J: CD28 ${ }^{-}$T cells: their role in the ageassociated decline of immune function. Trends Immunol 2009, 30:306-312.

22. Haringer B, Lozza L, Steckel B, Geginat J: Identification and characterization of IL-10/IFN-gamma-producing effector-like T cells with regulatory function in human blood. J Exp Med 2009, 206:1009-1017.

23. Steiner G, Tohidast-Akrad M, Witzmann G, Vesely M, Studnicka-Benke A Gal A, Kunaver M, Zenz P, Smolen JS: Cytokine production by synovial T cells in rheumatoid arthritis. Rheumatology 1999, 38:202-213.

24. van Baarsen LGM, Bos WH, Rustenburg F, van der Pouw Kraan TCTM, Wolbink GJJ, Dijkmans BAC, van Schaardenburg D, Verweij CL: Gene expression profiling in autoantibody-positive patients with arthralgia predicts development of arthritis. Arthritis Rheum 2010, 62:694-704

25. Emery P, Panayi GS, Nouri AM: Interleukin-2 reverses deficient cellmediated immune responses in rheumatoid arthritis. Clin Exp Immunol 1984, 57:123-129.

26. Seitz M, Napierski I, Kirchner H: Depressed PPD and tetanus toxoid presentation by monocytes to $\mathrm{T}$ lymphocytes in patients with rheumatoid arthritis: restoration by interferon gamma. Rheumatol Int 1988, 8:189-196.

27. Allen ME, Young SP, Michell RH, Bacon PA: Altered T lymphocyte signaling in rheumatoid arthritis. Eur J Immunol 1995, 25:1547-1554.

28. Thomas R, Mcllraith M, Davis LS, Lipsky PE: Rheumatoid synovium is enriched in CD45RB ${ }^{\text {dim }}$ mature memory $T$ cells that are potent helpers for B cell differentiation. Arthritis Rheum 1992, 35:1455-1465.

29. Berg L, Ronnelid J, Sanjeevi CB, Lampa J, Klareskog L: Interferon-gamma production in response to in vitro stimulation with collagen type II in rheumatoid arthritis is associated with HLA-DRB1 $\left({ }^{*}\right) 0401$ and HLA-DQ8. Arthritis Res 2000, 2:75-84.

30. Maurice MM, Lankester AC, Bezemer AC, Geertsma MF, Tak PP, Breedveld FC, van Lier RA, Verweij CL: Defective TCR-mediated signaling in synovial T cells in rheumatoid arthritis. J Immunol 1997, 159:2973-2978.

31. Berg L, Ronnelid J, Klareskog L, Bucht A: Down-regulation of the T cell receptor CD3 zeta chain in rheumatoid arthritis (RA) and its influence on T cell responsiveness. Clin Exp Immunol 2000, 120:174-182.

32. Wolf $\mathrm{M}$, Schimpl A, Hunig T: Control of T cell hyperactivation in IL-2deficient mice by CD4(+)CD25(-) and CD4(+)CD25(+) T cells: evidence for two distinct regulatory mechanisms. Eur J Immunol 2001, 31:1637-1645.

33. Ishimaru N, Kishimoto $H$, Hayashi $Y$, Sprent J: Regulation of naive $T$ cell function by the NF-KB2 pathway. Nat Immunol 2006, 7:763-772.

34. Berg L, Lampa J, Rogberg S, van Vollenhoven R, Klareskog L: Increased peripheral T cell reactivity to microbial antigens and collagen type II in rheumatoid arthritis after treatment with soluble TNFa receptors. Ann Rheum Dis 2001, 60:133-139.

35. van Amelsfort JM, Jacobs KM, Bijlsma JW, Lafeber FP, Taams LS: CD4(+) $\mathrm{CD} 25(+)$ regulatory $T$ cells in rheumatoid arthritis: differences in the presence, phenotype, and function between peripheral blood and synovial fluid. Arthritis Rheum 2004, 50:2775-2785.

36. Garcia de Tena J, Manzano L, Leal JC, San Antonio E, Sualdea V, AlvarezMon M: Distinctive pattern of cytokine production and adhesion molecule expression in peripheral blood memory $\mathrm{CD}^{+} \mathrm{T}$ cells from patients with active Crohn's disease. J Clin Immunol 2006, 26:233-242.

37. Nanki T, Lipsky PE: Cytokine, activation marker, and chemokine receptor expression by individual CD4(+) memory T cells in rheumatoid arthritis synovium. Arthritis Res 2000, 2:415-423.

38. Morita Y, Yamamura M, Kawashima M, Harada S, Tsuji K, Shibuya K, Maruyama K, Makino H: Flow cytometric single-cell analysis of cytokine production by $\mathrm{CD}^{+} \mathrm{T}$ cells in synovial tissue and peripheral blood from patients with rheumatoid arthritis. Arthritis Rheum 1998, 41:1669-1676. 
39. Assier E, Boissier M-C, Dayer J-M: Interleukin-6: from identification of the cytokine to development of targeted treatments. Joint Bone Spine 2010, 77:532-536.

40. Tortorella C, Schulze-Koops H, Thomas R, Splawski JB, Davis LS, Picker LJ, Lipsky PE: Expression of CD45RB and CD27 identifies subsets of CD4 ${ }^{+}$ memory $T$ cells with different capacities to induce $B$ cell differentiation. J Immunol 1995, 155:149-162

41. Chevalier N, Jarrossay D, Ho E, Avery DT, Ma CS, Yu D, Sallusto F, Tangye SG, Mackay CR: CXCR5 expressing human central memory CD4 T cells and their relevance for humoral immune responses. J Immunol 2011, 186:5556-5568.

42. Thewissen M, Somers V, Hellings N, Fraussen J, Damoiseaux J, Stinissen P: $\mathrm{CD}^{+} \mathrm{CD} 28^{\text {null }} \mathrm{T}$ cells in autoimmune disease: pathogenic features and decreased susceptibility to immunoregulation. J Immunol 2007, 179:6514-6523.

43. Buzás El, Végvári A, Murad YM, Finnegan A, Mikecz K, Glant TT: T-cell recognition of differentially tolerated epitopes of cartilage proteoglycan aggrecan in arthritis. Cell Immunol 2005, 235:98-108.

44. Di Mitri D, Azevedo Rl, Henson SM, Libri V, Riddell NE, Macaulay R, Kipling D, Soares MVD, Battistini L, Akbar AN: Reversible senescence in human $\mathrm{CD}^{+} \mathrm{CD}^{-}$RRA $\mathrm{R}^{+} \mathrm{CD} 27^{-}$memory T cells. J Immunol 2011, 187:2093-100.

45. Fujii H, Shao L, Colmegna I, Goronzy JJ, Weyand CM: Telomerase insufficiency in rheumatoid arthritis. Proc Natl Acad Sci USA 2009, 106:4360-4365.

46. Koetz K, Bryl E, Spickschen K, O'Fallon WM, Goronzy JJ, Weyand CM: T cell homeostasis in patients with rheumatoid arthritis. Proc Natl Acad Sci USA 2000, 97:9203-9208.

47. Schönland SO, Lopez C, Widmann T, Zimmer J, Bryl E, Goronzy JJ, Weyand CM: Premature telomeric loss in rheumatoid arthritis is genetically determined and involves both myeloid and lymphoid cell lineages. Proc Natl Acad Sci USA 2003, 100:13471-13476.

48. de Jong H, Berlo SE, Hombrink P, Otten HG, van Eden W, Lafeber FP, Heurkens AH, Bijlsma JW, Glant TT, Prakken BJ: Cartilage proteoglycan aggrecan epitopes induce proinflammatory autoreactive T-cell responses in rheumatoid arthritis and osteoarthritis. Ann Rheum Dis 2010, 69:255-262.

49. Mydel P, Wang Z, Brisslert M, Hellvard A, Dahlberg LE, Hazen SL, Bokarewa M: Carbamylation-dependent activation of T cells: a novel mechanism in the pathogenesis of autoimmune arthritis. J Immunol 2010, 184:6882-6890

50. Willemze A, van der Woude D, Ghidey W, Levarht EWN, StoekenRijsbergen G, Verduyn W, de Vries RRP, Houwing-Duistermaat JJ, Huizinga TWJ, Trouw LA, Toes REM: The interaction between HLA shared epitope alleles and smoking and its contribution to autoimmunity against several citrullinated antigens. Arthritis Rheum 2011, 63:1823-1832.

51. Deane KD, O'Donnell Cl, Hueber W, Majka DS, Lazar AA, Derber LA, Gilliland WR, Edison JD, Norris JM, Robinson WH, Holers VM: The number of elevated cytokines and chemokines in preclinical seropositive rheumatoid arthritis predicts time to diagnosis in an age-dependent manner. Arthritis Rheum 2010, 62:3161-3172.

\section{doi:10.1186/ar3848}

Cite this article as: Law et al:: T-cell autoreactivity to citrullinated autoantigenic peptides in rheumatoid arthritis patients carrying HLADRB1 shared epitope alleles. Arthritis Research \& Therapy 2012 14:R118.

\section{Submit your next manuscript to BioMed Central and take full advantage of:}

- Convenient online submission

- Thorough peer review

- No space constraints or color figure charges

- Immediate publication on acceptance

- Inclusion in PubMed, CAS, Scopus and Google Scholar

- Research which is freely available for redistribution

Submit your manuscript at www.biomedcentral.com/submit
Biomed Central 